\title{
Pengembangan Media Pembelajaran Flashcard Pada Pembelajaran Tematik Kelas IV SD Negeri 4 Srikaton
}

\author{
Author: \\ Okdiansyah ${ }^{1}$ \\ Tio Gusti Satria ${ }^{2}$ \\ Aswarliansyah ${ }^{3}$
}

Afiliation:

STKIP PGRI Lubuklinggau

Pendidikan Guru Sekolah

Dasar

Corresponding email

satriagustio@gmail.com

Histori Naskah: Submit: 2021-11-19 Accepted: 2021-11-24 Published: 2021-12-01

This is an Creative Commons License

This work is licensed under a Creative Commons Attribution-NonCommercial 4.0 International License

\begin{abstract}
Abstrak:
Penelitian ini bertujuan untuk mengembangkan produk pembelajaran berupa media pembelajaran flashcard pada pembelajaran tematik kelas IV SD Negeri 4 Srikaton yang valid dan praktis. Jenis penelitian ini yaitu research and development ( $\mathrm{R} \& \mathrm{D})$ dengan model pengembangan yang digunakan yaitu ADDIE. Sampel penelitian atau subjek penelitian ini yaitu siswa kelas IV yang berjumlah 9 orang siswa. Teknik pengumpulan data yang dilakukan melalui pengisian angket. Hasil penelitian menunjukan bahwa: 1) Kualitas Media dilihat dari aspek kevalidan termasuk dalam kategori sangat valid dengan persentase skor $83 \%$; 2) Kualitas Media dilihat dari aspek kepraktisan dikategorikan sangat praktis baik respon siswa secara perorangan dengan persentase skor $84,6 \%$, untuk persentase skor respon siswa kelompok kecil dengan nilai persentase skor $81,3 \%$ sedangkan untuk persentase skor respon guru dengan nilai persentase $90 \%$. Sehingga dapat disimpulkan bahwa Media pembelajaran Flashcard pada pembelajaran tematik memenuhi kriteria valid dan praktis serta dapat di gunakan dalam pembelajaran.
\end{abstract}

Kata kunci: Pengembangan, Media Pembelajaran Flashcard, Tematik

\section{Pendahuluan}

Pendidikan merupakan usaha dalam menciptakan sumber daya manusia yang makin bagus. Pendidikan berkembang menyertai perkembangan teknologi yang telah ada dan makin berkembangnya keahlian dalam pengetahuan. Pendidikan adalah bagian pokok yang diperhatikan untuk Indonesia karena adanya pelajaran yang sesuai serta pembagian dengan merata. Taraf pendidikan harus diperhatikan akan mencapai arah pendidikan. Sedangkan tingkatan sendiri bisa ditinjau dari kesuksesan yang dicapai bagi seorang pelajar selagi mengikuti aktivitas pembelajaran. Aktivitas pembelajaran hendaknya membuka kesempatan untuk menumpuk rasa ingin tahu anak didik secara alamiah. Hal ini akan membantu mereka mengembangkan kemampuan bertanya dan mencari jawaban atas berdasarkan bukti serta mengembangkan cara berfikir ilmiah. Salah satu untuk mengembangkannya adalah dengan pembelajaran tematik yang menyenangkan. Berdasarkan kurikulum 2013, pembelajaran tematik dibuat dalam bentuk tema (T. J. H. Tio Gusti Satria, 2020). Menurut Majid (Sa'dun Akbar, 2017) Pembelajaran tematik merupakan salah satu pendekatan pembelajaran yang menghubungkan berbagai bidang studi yang mencerminkan dunia nyata di sekeliling siswa dan dalam rentang kemampuan, perkembangan anak. (Kiki Yulia Silpiani, Elya Rosalina, 2020) Dalam proses pembelajaran tematik siswa diminta untuk lebih aktif dan mengeksplorasi konsep pembelajaran sendiri, dan guru hanya menjadi fasilitator dalam proses pembelajaran. Ada beberapa faktor di dalam pembelajaran Tematik yang harus dipenuhi diantaranya guru, siswa, dan media. guru merupakan seorang tenaga pendidik yang pekerjaanya membagikan ilmunya kepada siswa. Jika seorang guru dapat 
menyampaikan pembelajaran dengan baik, maka pada pembelajaran tematik dapat tersampaikan dengan maksimal. Bila seorang guru mengajar tidak sesuai dengan yang diharapkan maka materi tidak akan tersampaikan dengan maksimal pada proses pembelajaran berlangsung. Dengan adanya media pembelajaran guru dapat menyampaikan materi tematik secara efektif, membuat siswa lebih aktif pada saat proses pembelajran berlangsung. Apabila di dalam proses pembelajaran menggunakan media pembelajaran siswa akan senang, tidak mudah jenuh, siswa lebih aktif didalam kelas saat belajar.

Analisis kebutuhan yang dilakukan penulis pada tanggal 8 Januari 2021. Analisis kebutuhan guru dan siswa dilakukan melalui pengisian angket kepada wali kelas dan siswa IV SD Negeri 4 Srikaton. Berdasarkan hasil pengisian angket kebutuhan guru diperoleh bahwa di sekolah tersebut menggunakan kurikulum K-13, dengan jumlah siswa 23. Metode yang sering digunakan dalam proses pembelajaran metode ceramah, Tanya jawab, penugasan. Proses pembelajaran di masa pandemi Covid-19 dilakukan secara luring dan daring setiap masuk sekolah tatap muka siswa tetap mematuhi protokol kesehatan saat didalam kelas. Bahan ajar yang digunakan buku siswa dan buku guru. Kesulitan siswa dalam pembelajaran tematik yaitu materi yang disajikan sangat singkat dan terkadang siswa bingung dalam mengerjakan soal-soal dibuku tematik siswa. Guru kelas tersebut belum pernah menggunakan media kartu flashcard, media yang pernah digunakan yaitu infokus dan media karton. Perlu adanya media pemebelajaran agar siswa lebih aktif, semangat belajar dan membantu dalam proses pembelajaran. Guru kelas tersebut belum pernah menggunakan media yang berbentuk kartu bergambar. Siswa sangat senang belajar menggunakan media yang mengandung permainan karena siswa senang belajar sambil bermain.

Media pembelajaran Flashcard merupakan media pembelajaran berbentuk kartu bergambar dan berisi pertanyaan yang diterapkan melalui permainan kartu, kelebihan Media Pembelajaran Flashcard antara lain Praktis (tidak perlu menggunkan listrik), Mudah dibawa kemana-mana (ukuran yang kecil flashcard dapat disimpan didalam tas), Menyenangkan (Media Flashcard dalam penggunaannya dapat melalui permainan). Berdasarkan permasalahan di atas penulis akan mengembangkan sebuah media pembelajaran Flashcard untuk pembelajaran tematik kelas IV Sekolah Dasar. Oleh sebab itu, penulis mengambil judul penelitian yaitu "Pengembangan Media Pembelajaran Flashcard Pada Pembelajaran Tematik Kelas IV Sekolah Dasar Negeri 4 Sikaton".

\section{Studi Literatur}

Media pembelajaran merupakan segala sesuatu yang dapat digunakan menyalurkan pesan dari seorang guru kepada siswa yang dapat merangsang pikiran, perasaan, perhatian dan minat belajar siswa, sehingga terjadi proses pembelajaran yang efektif dan efisien (Nurdyansyah, 2019). Dalam media pembelajaran harus memperhatikan jenis-jenis media sebagai berikut: 1) Media visual contohnya gambar, foto, kartu, sketsa, peta. 2) Media audio contohnya rekaman, radio, laboraturium bahasa. 3) Media audio-visual contohnya film, slide. 4) Media teknologi gabungan contohnya media yang dikendalikan oleh komputer. Manfaat media praktis dari penggunaan media pembelajaran dalam proses belajar mengajar yaitu: a) Media pembelajaran dapat memperjelas pengajian pesan dan informasi sehingga dapat memperlancar dan meningkatkan proses dan hasil belajar siswa. b) Media pembelajaran dapat meningkatkan dan mengarahkan perhatian siswa sehingga dapat menimbulkan motivasi belajar, interaksi yang lebih langsung antara siswa dan lingkungannya, dan kemungkinan siswa untuk belajar sendiri-sendiri sesuai dengan kemampuan dan minat siswa. c) Media pembelajaran dapat mengatasi keterbatasan indera, ruang, dan waktu. d) Media pembelajaran dapat memberikan kesamaan pengalaman kepada siswa tentang peristiwa-peristiwa dilingkungan mereka, serta memungkinkan terjadinya interaksi langsung dengan guru, masyarakat, dan lingkungannya contohnya melalui karyawisata, kunjungan-kunjungan ke museum dan kebun binatang. (Azhar Arsyad, 2019). Media merupakan kata jamak dari medium yang artinya pengantar atau pelantara yang digunakan oleh pendidik untuk menyampaikan pesan kepada siswa dalam mencapaikan tujuan (Usep Kustiawan, 2013). Media Flashcard adalah media kartu yang berisi gambar, tulisan yang dapat dibuat 
sebagai permainan kartu sehingga sangat memungkinkan siswa tertarik untuk memahami materi yang disampaikan (Maghfiroh, 2013).

\section{Metode Penelitian}

Model pengembangan yang digunakan dalam penelitian ini adalah model pengembangan ADDIE untuk mengembangkan media pembelajaran. Model ADDIE memberi peluang untuk melakukan evaluasi terhadap aktivitas pengembangan pada setiap tahap.. Model pengembangan ADDIE ini memiliki empat tahapan pengembangan yaitu: Analisis (Analysis), Perancangan (Design), Pengembangan (Development), Implemintasi (Implemation), Evaluasi (Evaluation) (Hamzah, 2019).

.Metode yang dilakukan observasi. Pengumpulan data menggunakan angket respon guru dan peserta didik. Angket peserta didik adalah tehnik atau cara pengumpulan data secara tidak langsung (penulis tidak langsung bertanya-jawab dengan responden) dengan 10 pertanyaan. Angket ini berisi beberapa pernyataan yang kemudian akan dijawab dengan responden. Dengan kata lain angket adalah daftar pertanyaan yang akan diberikan kepada orang lain yang bersedia memberikan respon sesuai permintaan pengguna sedangkan angket respon guru.

Angket validasi bertujuan untuk mengetahui kevalidan media pembelajaran Flashcard. Instrumen yang digunakan untuk menganalisis kevalidan adalah angket penilaian yang diperuntukan ahli materi, ahli bahasa dan ahli media. Menghitung Skor Rata-rata Menghitung skor total rata-rata seluruh aspek yang dinilai dengan rumus sebagai berikut :

$$
\mathrm{P}=\frac{F}{\mathrm{~N}} \times 100 \%
$$

Sedangkan angket respon peserta didik bertujuan untuk mengetahui tingkat kepraktisan dari media pembelajran Flashcard Angket digunakan untuk pengumpulan data membuat daftar pertanyaan untuk mengetahui respon guru dan peserta didik mengenai media pembelajaran dan diberikan kepada para ahli yaitu: ahli materi, ahli bahasa dan ahli media Angket respon guru Angket dengan menggunakan 10 pertanyaan.

Instrumen yang digunakan untuk menganalisis kevalidan adalah angket penilaian yang diperuntukan angket respon guru dan peserta didik. Menghitung Skor Rata-rata Menghitung skor total rata-rata seluruh aspek yang dinilai dengan rumus sebagai berikut :

$$
\text { Tingkat Praktikalitas }=\frac{\text { Jumlah skor yang diperoleh }}{\text { Jumlah skor total }} \times 100 \%
$$

Dalam menganlisis instrumen penelitian, penelitian ini menggunakan uji validitas terlebih dahulu, untuk mengetahui valid dan praktis tidaknya suatu instrumen penelitian. Jika instrumen penelitian menunjukan hasil yang benar maka dikatakan valid dan praktis, tetapi jika instrumen penelitian menunjukan hasil di bawah rata-rata maka dikatakan tidak valid dan praktis.

\section{Hasil}

Setelah penelitian digunakan dengan menyebarkan angket respon peserta didik dengan 10 pertanyaan kepada 9 responden, kemudian diteliti satu persatu dan diberikan penilaian sesuai dengan jawaban 
Edu Cendikia: Jurnal Ilmiah Kependidikan

Volume: 1 | Nomor 3 | Desember 2021 | E-ISSN: 2798-365X | DOI: 10.47709/educendikia.vli3.1183

responden. Skor rata-rata yang diperoleh uji One to one 84,6. Kemudian skor rata-rata yang diperoleh uji Small Group 81,3.Sedangkan angket respon guru dengan 10 pertanyaan mendapatkan skor rata-rata 90. Nilai ini diperoleh dari pengisian kuesioner pnelitian yang memberikan informsi sebagai berikut: 5 (sangat praktis), 4 (praktis), 3 (cukup praktis), 2 (kurang praktis) dan 1 (tidak praktis).

Tabel 1. Hasil perhitungan angket uji one to one

\section{A. Respon Pesrta Didik Uji One to one}

\begin{tabular}{|c|c|c|c|c|c|c|c|c|c|c|c|c|}
\hline No & $\begin{array}{l}\text { Kode } \\
\text { Siswa }\end{array}$ & \multicolumn{1}{|c|}{ Nomor Pernyataan } & Jumlah \\
1 & S1 & 5 & 5 & 4 & 4 & 3 & 5 & 4 & 3 & 5 & 4 & 42 \\
2 & S2 & 4 & 5 & 5 & 4 & 4 & 4 & 3 & 5 & 4 & 3 & 41 \\
3 & S3 & 4 & 4 & 5 & 5 & 3 & 4 & 4 & 5 & 5 & 5 & 44 \\
\hline
\end{tabular}

Tingkat Praktikalitas $=\frac{\text { Jumlah skor yang diperoleh }}{\text { Jumlah skor total }} \times 100 \%$

$$
=\frac{127}{150} \times 100 \%=84,6
$$

Dapat kita simpulkan bahwa hasil akhir nilai respom peserta didik adalah 84,6 yang dikategorikan sangat praktis digunakan.

Tabel 2. Hasil perhitungan angket uji small group

\section{B. Respon Pesrta Didik Uji Kelompok Kecil (Small group)}

\begin{tabular}{|c|c|c|c|c|c|c|c|c|c|c|c|c|c|}
\hline \multirow{2}{*}{ No } & \multirow{2}{*}{$\begin{array}{c}\text { Kode } \\
\text { Siswa }\end{array}$} & \multicolumn{1}{|c|}{ N } & $\mathbf{2}$ & $\mathbf{3}$ & $\mathbf{4}$ & $\mathbf{5}$ & $\mathbf{6}$ & $\mathbf{7}$ & $\mathbf{8}$ & $\mathbf{9}$ & $\mathbf{1 0}$ & \multirow{2}{*}{ Jumlah } \\
\hline 1 & S1 & 5 & 5 & 4 & 3 & 5 & 4 & 3 & 3 & 3 & 5 & 40 \\
\hline 2 & S2 & 5 & 4 & 4 & 3 & 4 & 5 & 4 & 3 & 5 & 4 & 41 \\
\hline 3 & S3 & 4 & 4 & 5 & 3 & 5 & 3 & 4 & 4 & 3 & 4 & 39 \\
\hline 4 & S4 & 3 & 5 & 5 & 4 & 4 & 5 & 5 & 4 & 4 & 3 & 42 \\
\hline 5 & S5 & 4 & 3 & 4 & 3 & 4 & 5 & 4 & 4 & 4 & 4 & 39 \\
\hline 6 & S6 & 5 & 4 & 5 & 5 & 4 & 4 & 5 & 4 & 3 & 4 & 43 \\
\hline \multicolumn{8}{|c|}{} & \multicolumn{7}{|c|}{ Jumlah } \\
\hline
\end{tabular}




$$
\begin{gathered}
\text { Tingkat Praktikalitas }=\frac{\text { Jumlah skor yang diperoleh }}{\text { Jumlah skor total }} \times 100 \% \\
=\frac{244}{300} \times 100 \%=81,3 \%
\end{gathered}
$$

Dapat kita simpulkan bahwa hasil akhir nilai respom peserta didik adalah 81,3 yang dikategorikan sangat praktis digunakan.

\section{Respon Guru}

Tabel Hasil 3 Uji Kepraktisan Guru

\begin{tabular}{|c|c|c|c|c|c|c|c|c|c|c|c|}
\hline \multirow{2}{*}{ Subjek } & \multicolumn{10}{|c|}{ Nomor Pertanyaan } & \multirow{2}{*}{$\begin{array}{c}\text { Jumlah } \\
\text { Skor }\end{array}$} \\
\cline { 2 - 10 } & $\mathbf{1}$ & $\mathbf{2}$ & $\mathbf{3}$ & $\mathbf{4}$ & $\mathbf{5}$ & $\mathbf{6}$ & $\mathbf{7}$ & $\mathbf{8}$ & $\mathbf{9}$ & $\mathbf{1 0}$ & \\
\hline Guru Kelas & 5 & 5 & 4 & 4 & 4 & 5 & 5 & 4 & 4 & 5 & 45 \\
\hline \multicolumn{10}{|c|}{ Jumlah } \\
\hline
\end{tabular}

Tingakat Praktisan $=\frac{\text { Jumlah skor yang diperoleh }}{\text { Jumlah skor total }} \times 100 \%$

$$
=\frac{45}{50} \times 100 \%=90 \%
$$

Berdasarkan hasil uji kepraktisan guru yang diperoleh dapat disimpulkan bahwa respon guru terhadap media pembelajaran flashcard yaitu Sangat Praktis dengan persentase 90\%, sehingga media pembelajaran flashcard dapat digunakan dalam proses pembelajaran.

\section{Pembahasan}

Dari hasil pengujian yang dilakukan, didapatkan bahwa penilain pengembangan media oleh ahli media diperoleh rata-rata $70 \%$ atau valid. Sedangkan untuk ahli Bahasa diperoleh nilai rata-rata $90 \%$ yang berarti sangat valid. Hal ini layak untuk uji cobakan tanpa revisi. hal ini layak untuk di uji cobakan tanpa revisi dan untuk ahli materi diperoleh nilai rata-rata $89 \%$ yang berarti sangat valid dari segi materi. Hal ini layak untuk uji cobakan dengan revisi sesuai saran. Berdasarkan data pengisian angket oleh ketiga validator menunjukan bahwa dalam pengembangan media yang telah diperbaiki berdasarkan perhitungan data pengisian angket dengan skor rata-rata $83 \%$ dengan kriteria "sangat valid" dapat diartikan bahwa pengembangan Media Flashcard layak digunakan.

Pelaksanaan uji kepraktisan kelompok kecil yang terdiri 9 orang peserta didik. Berdasarkan hasil angket kelompok kecil yang diperoleh, dapat disimpulkan bahwa respon peserta didik dari uji one to one media Flashcard pada pembelajaran tematik adalah sangat praktis dengan skor rata-rata 84,6\%. (sangat praktis) sedangakan uji small group media Flashcard pada pembelajaran tematik adalah sangat praktis dengan skor rata-rata $81,2 \%$. Kemudian uji respon guru media Flashcard pada pembelajaran tematik adalah sangat praktis dengan skor rata-rata 90\%. Berdasarkan persentase keseluruhan nilai dari analisis perhitungan lembar angket uji kepraktisan media pembelajaran flashcard tergolong dalam kategori sangat praktis dengan persentase $83,2 \%$ artinya media pembelajaran flashcard yang telah dikembangkan sudah praktis untuk digunakan. 
Hasil penerlitian (Dessy Harisanty, 2020) Dari penggunaan media flashcard ini terlihat bahwa anak-anak usia sekolah dasar lebih menyukai dan tertarik dengan media yang dilengkapi dengan berbagai gambar dan memiliki warna yang beragam. Hal ini dikarenakan gambar dan warna yang beragam membuat mereka tidak cepat bosan saat menggunakannya, yang berbeda dengan buku karena kebanyakan buku hanya menyajikan satu gambar dan penuh dengan tulisan sehingga anak mudah merasa bosan. Penelitian lainnya dari (A. S. E. Tio Gusti Satria, 2020) yang telah dilakukan menunjukkan bahwa siswa membutuhkan penjelasan dari guru dalam bentuk nyata, akan tetapi karena guru tidak menggunakan media pembelajaran yang dapat menarik minat siswa dalam belajar. media pembelajaran mencakup manusia, materi atau kajian yang membangun suatu kondisi yang membuat siswa mampu memperoleh pengetahuan, keterampilan atau sikap. Sedangkan hasil penelitian (Ajeng Putri Utami, Tio Gusti Satria, 2021) Multimedia interaktif yang dihasilkan dikategorikan "valid" berdasarkan hasil penilaian multimedia interaktif yang dilakukan oleh tiga ahli (ahli bahasa, materi dan media). Multimedia interaktif yang dihasilkan dikategorikan "praktis" berdasarkan hasil penilaian multimedia interaktif yang dilakukan oleh guru dan siswa kelas V SDN 117/VII Perdamaian II terhadap multimedia interaktif yang telah dihasilkan.

\section{Kesimpulan}

Proses pembelajaran menggunakan media pembelajaran dapat membantu peserta didik untuk memahami materi. Kevalidan Media Pembelajaran Flashcard dinilai melalui hasil validasi para ahli antara lain: ahli media, ahli bahasa, dan ahli materi. Berdasarkan hasil validasi diketahui bahwa Media Pembelajaran Flashcard dikategorikan sangat valid dengan persentase kevalidan $83 \%$ sehingga Media pembelajaran flashcard pada pemeblajaran tematik dikategorikan sangat valid. Kepraktisan Media pembelajaran flashcard melalui angket yang diperoleh dengan dua tahap uji coba yang meliputi uji coba perorangan (one to one ) dan uji coba kelompok kecil ( small group ) dan uji kepraktisan guru melibatkan wali kelas 4. Berdasarkan hasil uji kepraktisan diperoleh persentase kepraktisan 83,2\%. Berdasarkan hasil uji coba tersebut diketahui respon siswa dan guru sangat baik yang diartikan bahwa Media Pembelajaran Flashcard pada pembelajaran tematik praktis dan mudah digunakan.

\section{Referensi}

Ajeng Putri Utami, Tio Gusti Satria, R. F. (2021). Pengembangan Multimedia Interaktif Pada Pembelajaran Tematik Tema Organ Gerak Hewan dan Manusia Kelas V SD. Jurnal Inovasi Pendidikan Dan Pembelajaran Sekolah Dasar, 5(2). https://doi.org/https://doi.org/10.24036/jippsd.v5i2

Azhar Arsyad. (2019). Media Pembelajaran. Rajawali Pers.

Dessy Harisanty, et al. (2020). The Utilization of Flashcards in Children Information Literacy

Development. Library Philosophy and Practice, 1-12.

https://digitalcommons.unl.edu/libphilprac/4554

Hamzah, A. (2019). Metode Penelitian dan Pengembangan Research and Development. Literasi Nusantara.

Kiki Yulia Silpiani, Elya Rosalina, T. G. S. (2020). Application Of Index Card Match Model In The Thematic Learning Of Class IV State SD 06 Srikaton Students. Literasi Nusantara, 1(1), 41-50. https://doi.org/https://doi.org/10.21107/literasinusantara.v1n1.091105

Maghfiroh, L. (2013). Penggunaan Media Flashcard Untuk Meningkatkan Hasil Belajar IPS 
Pada Pembelajaran Tematik Di Sekolah Dasar. Jurnal Penelitian Pendidikan Guru Sekolah Dasar, 1(2), 1-13. https://www.neliti.com/id/publications/250642/penggunaan-mediaflashcard-untuk-meningkatkan-hasil-belajar-ips-pada-pembelajara

Nurdyansyah. (2019). Media Pembelajaran Inovatif(U. Press (ed.)).

Sa'dun Akbar, et al. (2017). Implementasi Pembelajaran Tematik di Sekolah Dasar. PT Remaja Rosdakarya.

Tio Gusti Satria, A. S. E. (2020). Pengembangan Etnosains Multimedia Learning Untuk Meningkatkan Kognitif Skill Siswa SD di Kota Lubuklinggau. Basicedu, 4(1), 13-21. https://doi.org/https://doi.org/10.31004/basicedu.v4i1.382

Tio Gusti Satria, T. J. H. (2020). Development of Thematic Skill Learning Based on the 21th Century Skill Model for Fourth Graders. Journal of Teaching and Learning in Elementary Education (JTLEE), 3(1), 47-57. https://doi.org/http://dx.doi.org/10.33578/jtlee.v3i1.7825

Usep Kustiawan. (2013). Sumber dan Media Pembelajaran Anak Usia Dini. Universitas Negeri Malang. 